\title{
Discourses and Cracks
}

\section{A Case Study of Information Technology and Writing Women in a Regional Context}

\author{
ANNELIE EKELIN and PIRJO ELOVAARA \\ The Municipality of Ronneby annelie.ekelin@utb.ronneby.se, The University of \\ Karlskrona/Ronneby pirjo.elovaara@bib.hk-r.se
}

\begin{abstract}
This paper discusses information technology as political and practical discourse. This repetitive discursive model can be distinguished in global, regional and local contexts and contains an optimistic belief in technology as an independent power that automatically furthers democratic development. The second part of the paper presents empirical material and experiences from the 'Women Writing on the Net' project. The aim was to build up a virtual space for women and use writing as aim, tool and method. This created a more complex understanding of the values of the predominant IT discourses and revealed the 'cracks' and possibilities for feminist definitions of these values.
\end{abstract}

\section{INTRODUCTION}

"It seems that you need a Christmas tree," says the father in a contemplative voice. What do you do with a Christmas tree? The Moomin father is cautious: Here is the tree. Gafsan says that it has to be decorated. Do you know how to decorate a tree? After receiving advice from friends, they begin to understand that there are rules about how to decorate a tree. They use in their own special way shells and pearl necklaces. At the top, they place a red silk bow. "Goodness gracious me," says the hemule's aunt, "but you've always been a bit strange." "I think there ought to be a large star at the top," says the little mite's uncle. Do you think so? Is there such a big difference between the mere idea, and reality [8]?

What does the Christmas tree in the Moomin valley have to do with a discussion about information technology? If we regard the helpful friends' 
interpretations as the official version, we see that the text contains a number of questions which are central to this essay. Who decides that it is necessary to have a tree and who dictates how it should be decorated? What happens if we regard information technology discursively, just as the Moomin family views Christmas celebrations and the Christmas tree?

Let's start with the concept of discourse. It may be defined as "regulated, methodically organised discussion which dictates what may be said or done, and what may not be said or done" [9, p.39]. A discourse defines both values and the world. "The dominating, prevailing and predominant [discourses] are created by what is taken for granted and regarded as normal" [16, p.38] Discourses are born and brought to life in public texts and speeches. The dominant discourse is not hermetically sealed, however. There are always "cracks, or inadequacies" [6, p.25] "Wherever there is power, there is counter power" [10, p.52].

\section{THE PREDOMINANT IT DISCOURSE}

We can define IT-discourses on two levels: by analysing customary terms and concepts, and official policy documents. The neutral reading of the combination of letters IT can be understood as an abbreviation of the words Information and Technology. This is no longer a satisfactory reading, however, since IT has been transformed into a contemporary icon and represents many more values than the linguistic ellipsis. IT suggests, for example, abstract attributes, and it has certain life style connotations. It has also become a symbol of modernity, and is suggestive of numerous positive values, expectations and norms for living. IT, in other words, belongs to everyone, and the term successfully disguises the strong technical aspects.

IT may also be seen politically and practically. The repetitive discursive model can be distinguished in global, regional and local contexts. "[The] Internet is for everyone" was the theme of the conference organised by the ISOC. The Internet can be used to further the development of democracy as well as commerce. The "technological evolution" must continue if we are all to move towards a future without boundaries [4].

The chairperson for the IT Blekinge association, wrote, "we are entering a new society. Even now the very basis of everyday life is undergoing change...We know what we want to achieve: a higher quality of life, more jobs, democratic power for everyone, equality between men and women, the same preconditions for town and country, and more opportunities for the disabled" $[20,21]$. IT is both a catalyst and a tool in this process. Together, we are invited to join a new society. This invitation does not allow a negative response, however, and it does not allow us to keep the process at a 
distance. The transformation is inescapable. Citizens are given their portion of ready-made services and products, all of which have been developed and produced somewhere else, and at someone else's initiative.

Ronneby was one of the first municipal councils in southeast Sweden to invest in IT 'Ronneby in the year 2003, an IT society,' is the name of an umbrella project started by the council. The aim of the project is to coordinate, initiate and stimulate IT applications. "The project will give the inhabitants of Ronneby ample access to information technology. IT will be a democratic right. Dialogue and participation are key words. Renewal, initiative and variety will be furthered $[20,21]$.

The view that "IT is for everyone" is the common thread. This is the selfevident official device for our information society, where the Internet embodies accessibility, and is regarded as a democratic right. "The information society changes business and commerce, and democracy. Knowledge, which was once the privilege of the few, is open to everyone. Regional imbalances can be counteracted, productivity increased and new companies built. Information Technology must be a means of increasing freedom, participation and justice" [19], in the words of the Prime Minister of Sweden, in September 1999. The development of the hardware and software, and the building of the technological infrastructure presuppose speed, and the ability to act and make decisions [3]. A central feature is also the provision of instrumental training in the form of IT projects. These often resemble a literacy campaign for the general public. "But it is at least as important that everybody has the knowledge and self-confidence to make use of the technology" was the comment of some politicians [2]. The question is, does one really become more involved as a citizen by taking part in projects and courses whose aim is to teach basic computer skills? Can one really change the world by teaching people how to use Microsoft Word?

These visionary words (IT for everyone, accessibility, democracy, development and change) can be compared to mystical formulas which are constantly repeated in different official contexts. "Acceptable statements include: IT has developed fast, and will continue to do so; IT is the basis of the information society which has succeeded industrial society; IT creates new jobs; we must keep up and learn how to use IT; IT will lead to decentralisation and increased democracy; IT leads to globalisation, and a reduction in the power of nation-states" [9]. The above-quoted official texts constitute the dominant discourse, and fall within the limits of what is permissible. Technology is regarded as a self-evident driving force, and is both the end as well as the means. Characteristic of the belief in autonomous technological development is that it automatically furthers democratic development. IT is thus often presented in a well-camouflaged 'social suit.' In the same way, modern society demands a properly tailored 'technology 
suit.' The most suitable terms for the predominant IT discourse are thus 'democratic/technological' contra 'technological/democratic discourse'.

\section{DEMOCRACY AND CITIZENSHIP}

Does increased accessibility and the use of IT increase people's interest and involvement in democratic questions? We must start by asking the basic question, 'what is democracy?' By tradition, democracy implies participation, and certain rights [24]. This is what is normally dubbed 'universal citizenship'. It is important to remind ourselves that when democracy was born, it was based on the exclusion of women and other peripheral social groups [14, p.204]. The definition and application of democracy is based on a dichotomy or dualism between the public and the private [14, p.198]. The arena of citizenship is the public, the political arena. The majority of those acting in this arena are, as in the past, men. The private arenas include health care and care of the young and elderly, where it is women who have always been, (and indeed still are), the most active [14, p.198].

It is important to establish the official relationship between IT and democracy. Anders R. Olsson, author of a Swedish governmental report, presents three hypothetical models, which have been applied in the establishment of electronic democracy [17, pp.55-56, 62-63, 65]. As Olsson himself points out, however, "to start a discussion on electronic democracy with technical models is clearly putting the cart before the horse. It's important to know what you are trying to achieve with democracy before trying to make it electronic" [17, p.103]. The real issue becomes instead, "how do we get those citizens who are not interested in politics to become active and participate" [17, p.39]? Olsson's ideas are based on the fundamental principle that many citizens are neither interested nor involved. This lack of involvement, which is axiomatic, can, according to Olsson, be rectified by improving the spread of information. A more basic question is: "why is there such a lack of interest and involvement?" One possibility is that it is a kind of protest or a lack of subjective room for action (the ability to act and strength of initiative).

\section{ALL CITIZENS - EXCEPT WOMEN?}

Despite the strategy declared by the main actors of involving 'everyone' in the regional development of IT, it has been demonstrated by an investigation that women feel that they are excluded in the southeastern 
Sweden. The authors of the report write: "the dominance of the armed forces and major manufacturing companies has created a cultural tradition in which women are to a large extent invisible. It is almost exclusively men who dominate commerce and politics. And only men are appointed as directors in the public and private sectors" [1, p.40]. The report continues, "most of these women are pessimistic about their ability to exercise any influence in the following areas; housing, social services, leisure, communications, work and training. This feeling of lack of influence is, we believe, due to the fact that women do not feel themselves part of, or an asset in, regional development"'[1, p.42].

In western cultures, we often speak about democratic principles, which means, among other things, that we elect municipal councillors, municipal politicians and committees. Can we find any women in these bodies? The answer is both 'yes' and 'no' [20]. This picture is by no means unique for this region, or indeed for Sweden as a whole. Our belief is that the women taking part in the investigation regard themselves - and are seen by others to be - outsiders, strangers to political life. The question should instead be "why do women choose to be silent in public affairs?" What happens in a private context - is this a possible place for democracy?

\section{ALTERNATIVE DISCOURSES AND CRACKS}

Despite the fact that we have concentrated on the crystallisation of the predominant IT discourse, and found that the definition is closed and definitive, it is essential to remind ourselves that IT is a process, and a social construction, and it becomes possible to search for cracks. What happens when the IT mystical formula is translated into concrete actions and practices?

A concrete opportunity to stimulate an alternative understanding of IT appeared within the framework of an international IT project, the basic principles of which were identical to those already identified by us as the predominant values of the IT discourse. We chose, however, to analyse and take advantage of these values from a feminist perspective. This interpretation prepared the ground for a project based on a complex understanding of the discursive values: democracy, accessibility, change and development.

\subsection{The DIALOGUE Project and the WWN Project}

The trans-European DIALOGUE project started in 1998 and ran to spring 1999 [5]. The project was characterised by democratic profile, and aimed at 
developing the use of IT as a means of furthering democracy and methodological development.

The 'Women Writing on the Net' (WWN) project began as a sub-project within the framework of DIALOGUE. The overall aims of the project were to further grass roots democracy by working with empowerment, to conquer and re-define the public arena, to stop the drawing up of boundaries or dualism between public/private or expert/non-expert and to build virtual communities.

By using their own experience as a source of knowledge, women were able to renew the value and strength of these experiences. Our vision was to weave together the overall goals with the practical working methods and the individual elements of the project. The project was also responsible for bringing about a physical meeting between Swedish and immigrant women.

An essential part of the project was the methodological development, which focused on the learning process in a specific social context. The aim was to give time and space to writing, discussions and reflection and to combine this with IT training as a means of integrating action and reflection.

The starting point of the project was that people would all learn together, by co-operating with and meeting one another, by sharing knowledge and experience, and by interpreting and formulating - on a mutual as well as an individual basis - understandings in words and thoughts as well as in writing $[18,23]$.

\subsection{Writing as Aim, Tool and Method}

Writing during the project played an important role on several different levels simultaneously. If one sees speaking as a political act and political tool, communication between people and the development of the individual voice is fundamental to the development of democracy [11]. It is still writing and the ability to express oneself verbally which is the basis of all communication and interaction on the Internet. We considered it essential that the individual be able to rely on his or her own voice, and we stressed the importance of the written word as well as the potential of IT as a voice amplifier and megaphone [15, p.187].

\subsubsection{The Home}

A vitally important part of making the results of the women's work visible was to initiate the creation of virtual fellowships and communities. The web site of the WWN project took the form of a four-roomed house. This graphical design was inspired by Virginia Woolf's thoughts in the classic essay "A Room of One's Own" [25]. Times may well have changed 
but the woman's need of a space of her own, where she can think and feel at leisure, and where personal expression is permitted to grow and develop, is every bit as important today. This can be put to private use, and on one's own conditions, by creating a symbolic and real room on the Internet. The latter can be furnished with one's own thoughts, visions and dreams. It can also be seen as a way of re-conquering the symbol of 'the home,' which throughout history has closed in the woman in the private sphere, and shut her out of the public one [13, p.31-34].

\subsubsection{Individual, Collective and Public Writing}

The rooms represent also different aspects of writing. The four rooms consist of the Portrait Gallery, the Individual's Own Room (poems and stories), our Pantry (recipes and gastronomic memories) and the Discussion room (a forum for discussions). The categories are neither clear-cut nor separate, however. In the Discussion room, for example, a wide range of topics is discussed, from the existence or otherwise of rhyme forms, funny stories about the wisdom of children, the problem of unemployment, and anger at the bombing of Kosovo. In the Individual's Own Room, there is a description of a family party described through the eyes of a child, and an authentic description of class differences in modern Sweden.

\subsubsection{Writing Together}

Our Pantry, or the virtual cookery book is an example of writing together, the aim of which is to draw out invisible knowledge and experience. Another example of joint writing within the group is the latter's collective effort to formulate questions for local politicians.

Judging by the evaluations, the experience of being able to write - both as an individual as a member of a group - being able to transform material for a home page, discuss writing in general and produce personal texts to be read out loud to the group, has been the most important result of the project as for the participants.

\section{CONCLUSION}

Let us give the final words to the WWN project: Cracks make possible small projects with a definite time limitation, as well as a number of other activities -- but is it permissible to re-create the predominant IT discourse so that it is given a new nuance, and becomes deeper? Place, time and money are fixed factors, but the effects are restricted by these preconditions just as 
the project form itself has fixed time limits. Is the demand for involvement genuine? We must not forget the new experiences of the participants, and we shouldn't belittle the value of their experiment. And we continue to re-create the discourses.

\section{REFERENCES}

1. Andersson, B. \& Rosenqvist, A. (1998) Kvinnobilder av Blekinge: en rapport från projektet Kvinnors visioner om det framtida Blekinge. Lund.

2. Andersson, E. \& Daléus, L. Låt inte IT-användningen bli en klassfråga, http://www.centerpartiet.sel.

3. Bildt, C. (11/1998) Carl Bildt veckobrev v. (Carl Bildt's Weekly Letter), http://www.moderat.se/index.asp? main=ideer asikter/index.asp

4. Cerf, V. The Internet is for Everyone, http://www.isoc.org/isoc/media/speeches/foreveryone.shtml

5. Dialogue, http://www.ronneby.se/dialogue/, http://www.ronneby.se/dialogue/storybook/default.htm http://www.connected.org/methods/intro.html

6. Fahlgren, S. (nr 23, 1998). Diskursanalys, kunskap och kön: ett försök att utveckla en teoretisk ram och ett arbetssätt för en diskursanalys av vetenskapliga texter Umeå Umeå Universitet, Institutionen för socialt arbete.

7. (1996). Hur ska vi i Blekinge använda IT? Karlskrona,

8. Jansson, T. (1986). Det osynliga barnet och andra berättelser. Stockholm.

9. Johansson, M. \& Nissen, J. \& Sturesson, L. (1986). IT-ism: informationstekniken som vision och verklighet. (Via Teldok 32, KFB-rapport 1998:11). Stockholm.

10. Järvinen, M. (1996). Makt eller vanmakt? In Kvinnovetenskaplig tidskrift. 1, 47 - 62

11. Kahlert, H. (1997). Feminist Perspectives on Democratization. In Women, work and computerization: Spinning a Web from Past to Future. In Proceedings of the $6^{\text {th }}$ international IFIP conference. Berlin.

12. Kvinnor skriver på nätet, http://www.ronneby.se/dialogue/Ksn/wwn.htm

13. Leigh Star, S. (1996). From Hestia to Home Page: Feminism and the Concept of Home in Cyberspace. In Lykke, N. \& Braidotti, R. (Eds.). Between Monsters, Goddesses and Cyborgs: Feminist Confrontations with Science, Medicine and Cyberspace. London.

14. Lister, R. (1997). Citizenship: Feminist Perspectives, Houndmills.

15. McKay, A. (1988). Speaking up: Voice Amplification and Women's Struggle for Public Expression. In Kramarae, C. (Ed.). Technology and Women's Voices: Keeping in Touch. New York,

16. Mörtberg, C. (1997). Det beror på att man är kvinna . . gränsvandrerskor formas och former informationsteknologi. Luleå.

17. Olsson, A. R. (1999). Elektronisk demokrati. Demokratiutredningens skrifter $n r 16$ (Statens offentliga utredningar 1999:12), Stockholm.

18. Papert, S. (1994). Hur gör giraffen när den sover. Göteborg.

19. Persson, G. (1999-09-14). Öppnandet av Riksmötet.Regeringsförklaring av Göran Persson, http://www.riksdagen.se/debatt/9900/prot/2/htframe.htm

20. Ronneby kommun (a) $h t t p: / / w w w . r o n n e b y . s e$

21. Ronneby kommun (b): Paraplyprojekt 2003, http://www.ronneby.se/ronneby(infoc/projekt/2003proj.html 
22. Ronneby kommun (c): IT i Ronneby Nyhetsbrev (Newsletter), http://www.ronneby.se/ronneby/infoc/projektnyhetsvrev/lista.html

23. Turkle, S. (1997). Leva.online (Life on the Screen), Stockholm.

24. Voet, R. (1993). Women as Citizens and the Role of Information Technology. In Beardon, C. \& Whitehouse, D. (Eds.).Computers and Society. by, Oxford.

25. Woolf, V. (1958). Ett eget rum och andra essäer (A room of One's Own and Other Essays), Stockholm. 